\title{
Structural and sedimentological analysis of the Pliocene-Late Miocene deposits from the Romanian Black Sea offshore based on borehole electrical imaging
}

\author{
Bogdan Mihai Niculescu*, and Gina Andrei \\ University of Bucharest, Faculty of Geology and Geophysics, Department of Geophysics \\ 6 Traian Vuia Street, 020956 Bucharest, Romania
}

\begin{abstract}
This study presents the results of the structural and sedimentological interpretation of borehole electrical imaging data recorded in a gas exploration well from the Romanian offshore area of western Black Sea. The well intercepted on the investigated interval Pliocene to Late Miocene deposits, including a gas reservoir hosted in Early Pliocene shallow marine sands and silts. A total of 824 features were picked on the electrical image, such as bedding, soft sediment deformations, open (conductive) fractures and closed (resistive) fractures. An analysis of the dip angles and azimuths data identified four structural domains within the study interval: two are quasi-horizontal, one shows slightly inclined bedding dips and one is dominantly deformed (slump features and possibly sediment creep). The open fractures show a preferential WNW-ESE strike, whereas the closed fractures show, besides a WNW-ESE strike, mostly ENE-WSW to N-S strikes. The opposite directions of the two fracture sets suggest a relationship to the regional tectonic stress, with open fractures being nearly parallel to maximum horizontal stress SHmax direction and closed fractures being nearly normal to SHmax direction. The variable bioturbation intensity observed on the electrical image may reflect salinity fluctuations in the Black Sea basin.
\end{abstract}

Keywords: bioturbation, Black Sea offshore, borehole imaging, fractures, soft-sediment deformations, tectonic stress

\section{Introduction}

The introduction and development of borehole electrical imaging tools have enabled geoscientists to obtain valuable high-resolution information regarding the characteristics and details of the formations intercepted by exploration wells.

Such information can be used for structural interpretations (structural dip, faults and fractures characterization, in-situ tectonic stress orientation), sedimentological

\footnotetext{
*Corresponding author: bogdan.niculescu@gg.unibuc.ro
} 
interpretations (facies analysis, depositional environments, bioturbation, paleocurrents), and petrophysical applications (thin-bed reservoir analysis, net sand definition, characterization of permeability heterogeneity, identification of flow baffles/barriers) essential to reservoir simulation studies.

Electrical imaging tools produce core-like imagery of the borehole wall from highresolution oriented microresistivity/microconductivity data, the images being interpreted by picking out and classifying contrasting features (planar or non-planar). The wireline tools which can be run in water-based drilling muds include the Formation Microscanner (FMS) and Fullbore Formation MicroImager (FMI) - Schlumberger, Electrical MicroImaging Tool (EMI) and X-tended Range MicroImager (XRMI) - Halliburton, Simultaneous Acoustic and Resistivity Borehole Imager (STAR) - Baker Atlas/Baker Hughes, and Compact MicroImager (CMI) - Weatherford [1, 2].

On the Romanian Black Sea continental shelf the Miocene-Pliocene succession is welldeveloped and is characterized by a complex sedimentary evolution, due to the variable sediment supply from land, the tectonic activity and subsidence, and the sea level fluctuations. These deposits host the biogenic gas system of the western Black Sea, with numerous gas shows and commercial accumulations $[3,4]$. The drilling of a gas exploration well in the Histria basin offshore Romania, which benefited from a complex geophysical investigation program including electrical imaging, provided an opportunity for a detailed characterization of the intercepted Pliocene to Late Miocene deposits, from a structural and sedimentological viewpoint. This study uses electrical imaging data made available by the Romanian oil - gas industry and presents the processing methodology and the main results of the interpretation, aiming to integrate them into the broader geological context of the Romanian Black Sea offshore area.

\section{Geological-tectonic setting and hydrocarbon accumulations}

The Romanian part of the western Black Sea basin is an important hydrocarbon-bearing region in SE Europe. This margin of the Black Sea comprises three main geotectonic units, separated by major faults: the Scythian and Moesian platforms in the Carpathian foreland, located south of the East European Platform, and in between these platforms the North Dobrogea Orogen. Geophysical and borehole data show that the current structure of the Black Sea margin in Romania resulted through displacements along major faults, striking WNWESE and extending NW to the East Carpathians bend zone.

Seismic studies in the Black Sea have identified the prolongation of major crustal faults on the continental shelf, as well as secondary NW-SE faults of the same fault systems. This system is affected by another system of major faults oriented approximately N-S or NNESSW, generating a block structure with vertical displacements [3].

Up to now, on the Romanian continental shelf, the main area of interest from the perspective of hydrocarbons potential is the Histria Depression/sedimentary basin, a posttectonic cover superimposed over the North Dobrogea Orogen, formed by extension beginning with Aptian-Albian and until Eocene, then followed by subsidence [3]-[5]. This NW-trending depression located in the central area of the Romanian continental shelf is bounded by a major structural feature, the "Euxinic Threshold", which may represent a continental palaeoslope developed during the Late Eocene, but also the limit of the shelf deposits during the Late Cretaceous [5]. 


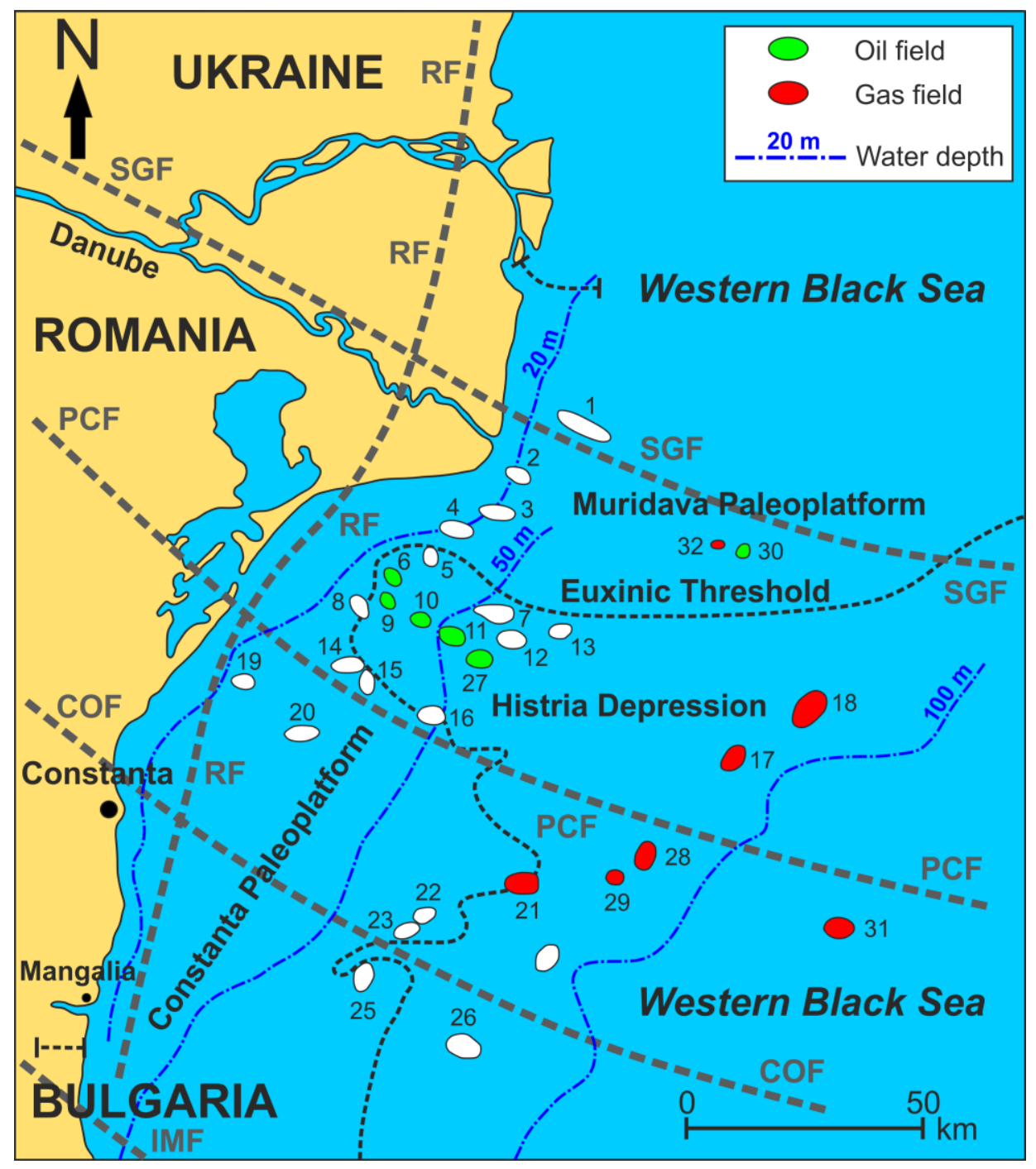

Fig. 1. Location map of the Romanian Black Sea shelf showing the main plays and leads, and major structural-tectonic features. 1 - Pelican, 2 - Sf. Gheorghe, 3 - Sacalin, 4 - Sturion, 5 - Egreta, 6 Portiţa, 7 - Heracleea, 8 - Venus, 9 - Sinoe, 10 - Lebăda-W, 11 - Lebăda-E, 12 - Minerva, 13 Albatros, 14 - Iris, 15 - Lotus, 16 - Tomis, 17 - Ovidiu, 18 - Cobălcescu, 19 - Vadu, 20 - Corbu, 21 - Midia, 22 - Meduza, 23 - Neptun, 24 - Neptun-E, 25 - Delfin, 26 - Jupiter, 27 - Pescăruş, 28 Doina, 29 - Ana, 30 - Muridava (Olimpyska), 31 - Domino, 32 - Eugenia. SGF - Sfântu Gheorghe fault, PCF - Peceneaga-Camena fault, COF - Capidava-Ovidiu fault, IMF - Intramoesian fault, RF Razelm fault (adapted from [3], [4] and [6]).

In Histria sedimentary basin oil-bearing reservoirs have been identified in Albian, Late Cretaceous (Turonian, Coniacian, Santonian), Eocene and Oligocene formations, whereas gas shows or commercial gas accumulations are located in Cretaceous, Eocene and especially Late Miocene-Early Pliocene (Pontian and Dacian) formations [3, 4, 6]. In pre-Oligocene and Oligocene formations, the traps are either tectonic (anticlines, faulted anticlines) or stratigraphic (pinchouts, drape anticlines). In post-Oligocene formations, the traps are of stratigraphic type, such as depositional fans or anticlines of differential setting, extended over wide areas and sometimes affected by gravity faults and growth faults. 
According to [4], four thermogenic petroleum systems and one biogenic gas system are present in the Romanian continental shelf area of the western Black Sea. To date, the biogenic system comprises the Midia, Ovidiu, Cobălcescu, Ana, Doina and Domino gas fields. Gas is located in Pontian-Dacian sands; the source rocks are considered to be the Middle-Late Miocene (Sarmatian or Early Pontian) pelitic deposits and the seals can be represented by all pelitic Pliocene intervals. The traps for the biogenic gas system include drape anticlines, rollover anticlines, monocline beds affected by listric faults and stratigraphic traps.

Sea-level changes during the Neogene led to a complex sedimentary development on the Romanian Black Sea shelf, with periods of intense sedimentation followed by nonsedimentation and erosion. The Miocene-Quaternary succession can be divided into several units: Badenian-Sarmatian, Pontian, Dacian, and Romanian-Quaternary. The boundary between the Romanian stage and the Quaternary formations is conformal, as is the base of the Romanian. Major erosional unconformities have been mapped using seismic data at the base of the Badenian (marking the boundary between Oligocene and Badenian-Sarmatian sequences), base of Pontian, intra-Pontian (three unconformities), and base of Dacian.

Seismic and borehole data show that whereas the Badenian-Sarmatian section occurs only locally on the inner and middle shelf areas and is very thin (up to $245 \mathrm{~m}$ thickness), the Pontian is widespread over the shelf and increases in thickness from the coast basinward, reaching thicknesses of about $4000 \mathrm{~m}$ on the outer shelf. The Dacian and RomanianQuaternary successions are also widespread over the shelf, but are thinner than the Pontian, with a maximum thickness of $1150 \mathrm{~m}$ and $575 \mathrm{~m}$ respectively on the continental slope [5].

The exploration well taken into consideration in this study was drilled in Histria Depression, reaching a total depth of $1275 \mathrm{~m}$ and crossing the following stratigraphic succession: Pleistocene-Holocene (Quaternary): 93.5-565 m (68.5-540 m TVDSS - true vertical depth subsea), Romanian (Late Pliocene): 565-773 m (540-748 m TVDSS), Dacian (Early Pliocene): 773-1244 m (748-1219 m TVDSS), Pontian (Late Miocene): 1244-1275 $\mathrm{m}$ (1219-1250 m TVDSS).

The well intercepted a gas reservoir hosted in a four-way dip closure structure by Dacian sands. The reservoir top is located at $1139 \mathrm{~m}$ (1114 m TVDSS). The sands are immature, poorly consolidated (little or no authigenic or diagenetic cement), fine to very fine grained, muddy to silty, sometimes thinly bedded, and strongly bioturbated. Core observations from the main reservoir interval suggest that the overall depositional environment was probably shallow marine, in water depths between 25 and $100 \mathrm{~m}$ (lower shoreface to upper offshore regime), with frequent sediment influx being provided from a delta system situated approximately to the NW. In the analyzed well a vertical variability of the reservoir intervals grain size can be observed, allowing their separation into a "Sand" upper facies (good reservoir quality, fine sands) of $27 \mathrm{~m}$ thickness and a "Silt" bottom facies (poor reservoir quality, silty sands, silts and muddy silts) of $39 \mathrm{~m}$ thickness. This upward-sanding succession is interpreted as a progradational parasequence.

\section{Data and methodology}

The wireline logging investigation program for the analyzed well included an electrical imaging log, which was recorded in the 8.5-inch borehole section over the depth interval 649-1272 m (624-1247 m TVDSS) (Fig. 2). The imaged interval covered mostly Romanian and Dacian deposits, only $28 \mathrm{~m}$ being recorded in Pontian.

The electrical imaging tool used is a four-arm, pad-based microresistivity device. It has four orthogonal imaging pads, each with a hinged and vertically-offset flap, to increase borehole coverage. 


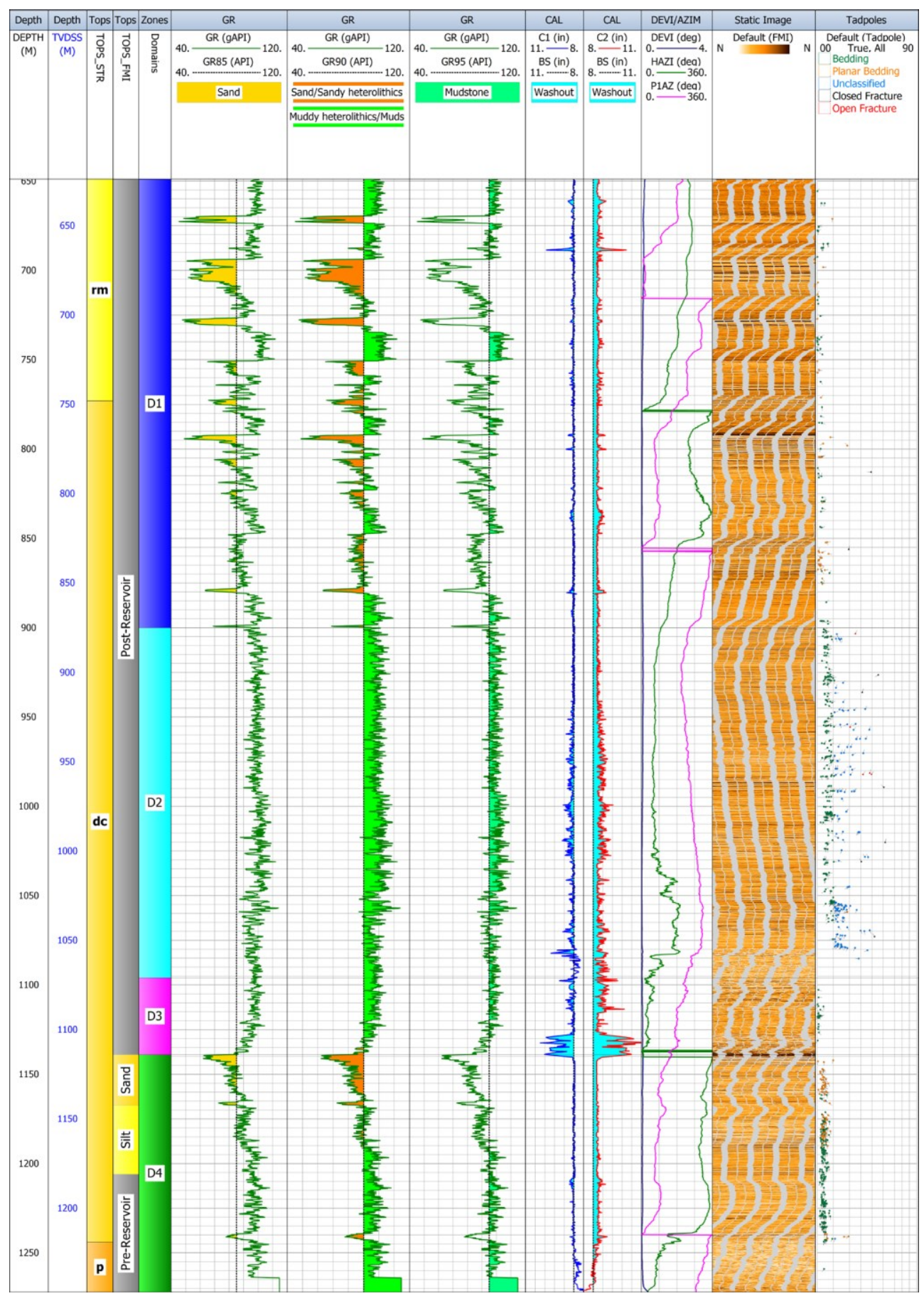

Fig. 2. Borehole electrical imaging data recorded in the Pliocene-Late Miocene deposits intercepted by the analyzed exploration well (tracks 6-11, from left to right) and partial results of the data processing and interpretation (tracks 12-13). rm - Romanian stage; $\mathbf{d c}$ - Dacian stage; $\mathbf{p}$ - Pontian stage; D1 to D4 - interpreted structural domains; GR - total natural gamma-ray log; GR85, GR90, GR95 - gamma-ray cut-off values; BS - bit size; C1, C2 - perpendicular caliper logs; DEVI borehole inclination; HAZI - borehole azimuth; P1AZ - azimuth of tool's reference pad (pad \#1). 
Each pad and flap has 24 electrode buttons arranged in two horizontally-offset rows, therefore 192 button readings are acquired in each increment. The tool arms are linked as opposing pairs (1-3 and 2-4) such that each arm-pair moves in step to ensure good centralization. Measurements are made by causing a current to flow from each electrode button through the formations. As each button touches the formation, the current path is strongly affected by resistivity/conductivity variations at the point of contact. The buttons measure formation microresistivity on a $2.5 \mathrm{~mm}$ vertical increment and horizontal spacing. This allows a $5 \mathrm{~mm}$ intrinsic tool resolution under optimal conditions. Raw data consist of multiple electrode readings, caliper readings from individual pads or pairs of pads, and $\mathrm{x}-, \mathrm{y}-$, and $\mathrm{z}$-axis accelerometer and magnetometer readings. Borehole deviation and pad 1 (tool) orientation are determined from the magnetometers [2].

The corrections that have been applied to the raw imaging data included: filling data gaps, accelerometer correction, depth alignment of microresistivity traces, gain correction and dead/faulty buttons corrections. Static and dynamic borehole images were created from the corrected electrical data by assigning color maps to ranges of resistivity values. By convention, low-resistivity features, such as shales or fluid-filled fractures, are displayed as dark colors and high-resistivity features are displayed as light colors. The static image (Fig. 2 - track 12/“Static image") has a single resistivity/color map contrast setting applied for the entire well. The dynamic image has a variable resistivity/color map contrast applied in a moving window and it provides enhanced views of features such as bed boundaries, fractures, vugs, and sedimentary features. For visualization, the borehole images are split along true north then the cylinder is unrolled, becoming an oriented 2D view (left side $-0^{\circ}$ and right side $-360^{\circ}$ correspond to true north). Dipping planar features/surfaces that intersect the cylindrical borehole appear as sine waves in the $2 \mathrm{D}$ views, whereas the horizontal or vertical features/surfaces will remain horizontal or vertical $[1,2]$.

A semi-automatic sine-curve fitting technique was used to obtain the dips of the planar features identified on the images. The computed tadpoles (dip angle and dip azimuth values) corresponding to these features (Fig. 2 - track 13/“Tadpoles") allowed a statistical analysis (Fig. 3) and a separation into domains of the investigated interval.

The comparison of a core (extracted from the depth interval 1143-1155 m) facies against features apparent on the electrical image and their associated conventional open hole well $\log$ responses indicated that the electrical image facies can be identified based on lithology, bioturbation intensity, and sedimentary structure. Lithology was primarily evaluated from a combination of conventional well log responses and character of the statically-normalized electrical image.

\section{Results and discussion}

A total number of 824 planar electrical features were identified on the imaged interval, each feature being assigned to a geological category (Table 1). The generic "Unclassified" category comprises higher-angle planar features from shaly intervals, which may be of sedimentary or structural origin. The "Planar bedding" category refers only to the planar features identified in sandy intervals, although non-planar features were also recognized. To associate the electrical features with certain formations, the lithology was interpreted and separated into four general classes based on a combination of natural gamma-ray, neutron porosity, bulk density, and electrical imaging log responses (Table 2).

From a structural viewpoint, four distinct domains were delineated in the imaged interval (Table 3). Domains D1 and D3 are essentially horizontal, whereas domain D4 shows slightly inclined bedding dips. Domain D2 is dominantly deformed, small-scaled slump features and possible sediment creep being observed. Dip azimuth orientations swing anticlockwise from $\mathrm{S}$ at the base of the study interval to SE or E at the top of the interval. 
Table 1. Planar features picked on the borehole electrical images.

\begin{tabular}{|c|c|c|}
\hline Category & Number & Remarks \\
\hline Bedding & 517 & $\begin{array}{l}\text { In mudstones/shales and muddy heterolithics (dip angles } \leq \\
\left.10^{\circ}\right) ;\end{array}$ \\
\hline Unclassified & 155 & $\begin{array}{l}\text { In mudstones/shales and muddy heterolithics (dip angles }> \\
\left.10^{\circ}\right) ;\end{array}$ \\
\hline Planar bedding & 139 & In sands/sandstones and sandy heterolithics (any dip angles); \\
\hline Closed fractures & 8 & Resistive, potentially normal to $S H$ max $^{*}$ stress orientation; \\
\hline Open fractures & 5 & $\begin{array}{l}\text { Conductive, potentially sub-parallel to SHmax stress } \\
\text { orientation. }\end{array}$ \\
\hline
\end{tabular}

* SHmax - present-day maximum horizontal stress orientation.

Table 2. Lithology identification criteria from conventional well logs and electrical imaging data.

\begin{tabular}{|c|c|c|c|}
\hline Lithology & $\begin{array}{c}\text { GR } \\
{[\mathrm{API}]}\end{array}$ & $\begin{array}{c}\text { Density-Neutron } \\
\text { crossover }\end{array}$ & $\begin{array}{c}\text { Electrical } \\
\text { imaging }\end{array}$ \\
\hline Sand/Sandstone & $<85$ & Sandstone response & Resistive beds \\
\hline Sandy heterolithics & $<90$ & $\begin{array}{l}\text { Marginal sandstone } \\
\text { response }\end{array}$ & $\begin{array}{l}\text { Mixed resistive and } \\
\text { conductive beds }\end{array}$ \\
\hline Muddy heterolithics & $90-95$ & $\begin{array}{l}\text { Marginal mudstone } \\
\text { response }\end{array}$ & $\begin{array}{l}\text { Mixed conductive and } \\
\text { resistive beds }\end{array}$ \\
\hline Mudstone/Shale & $>95$ & Mudstone response & Conductive beds \\
\hline
\end{tabular}

Table 3. Structural zonation of the analyzed exploration well - domains identified.

\begin{tabular}{ccl}
\hline Domain & $\begin{array}{c}\text { Depth interval } \\
{[\mathrm{m}]}\end{array}$ & \multicolumn{1}{c}{ Characterization } \\
\hline $\begin{array}{c}\text { D1 } \\
\text { (101 picks) }\end{array}$ & $649-900$ & $\begin{array}{l}\text { Generally horizontal bedding within a mixed succession of } \\
\text { mudstones/shales, heterolithic beds and sandstones; }\end{array}$ \\
D2 & $900-1096$ & $\begin{array}{l}\text { Interval of frequent soft sediment deformations and with a } \\
\text { change in palaeoslope orientation (towards E-NE and SW); } \\
\text { (403 picks) }\end{array}$ \\
D3 & $1096-1139$ & $\begin{array}{l}\text { Generally horizontal bedding, succession of mudstone/shale } \\
\text { beds with a predominant SE azimuth direction; }\end{array}$ \\
(20 picks) & $1139-1272$ & $\begin{array}{l}\text { Includes the main gas-bearing reservoirs and underlying } \\
\text { stratigraphic intervals and shows an overall shallow structural } \\
\text { D4 }\end{array}$ \\
(300 picks) & & towards S-SSE. \\
\hline
\end{tabular}

Fractures were rarely observed, mainly in the structural domains D1 and D2. They are more frequent in domain D2 (Fig. 4) where they may be related to sediment deformation.

The open/conductive fractures show a consistent NNE dip azimuth (average dip azimuth: $28^{\circ}$; average dip angle: $\left.31^{\circ}\right)$ and a preferential ESE-WNW strike $\left(120^{\circ}-300^{\circ}\right)$. This strike agrees well with the general direction of one of the major fault systems in this area, including crustal faults such as Sfântu Gheorghe fault, Peceneaga-Camena fault, Capidava-Ovidiu fault and Intramoesian fault.

The closed/resistive fractures show both NNE and WNW dip azimuths (average dip azimuths: $14^{\circ}$ and $296^{\circ}$, respectively; average dip angle: $38^{\circ}$ ). For these fractures, besides a ESE-WNW strike $\left(104^{\circ}-284^{\circ}\right)$, also ENE-WSW to N-S strikes are present. The resistive fractures with NNE dip azimuths/ESE-WNW strikes could be explained by the presence of resistive fracture-filling minerals deposited in pre-existing open fractures.

The opposite directions of the two fracture sets suggests a relationship to the regional tectonic stress, with open fractures being nearly parallel to the present-day maximum horizontal stress direction (SHmax) and closed fractures being nearly normal to SHmax direction. 


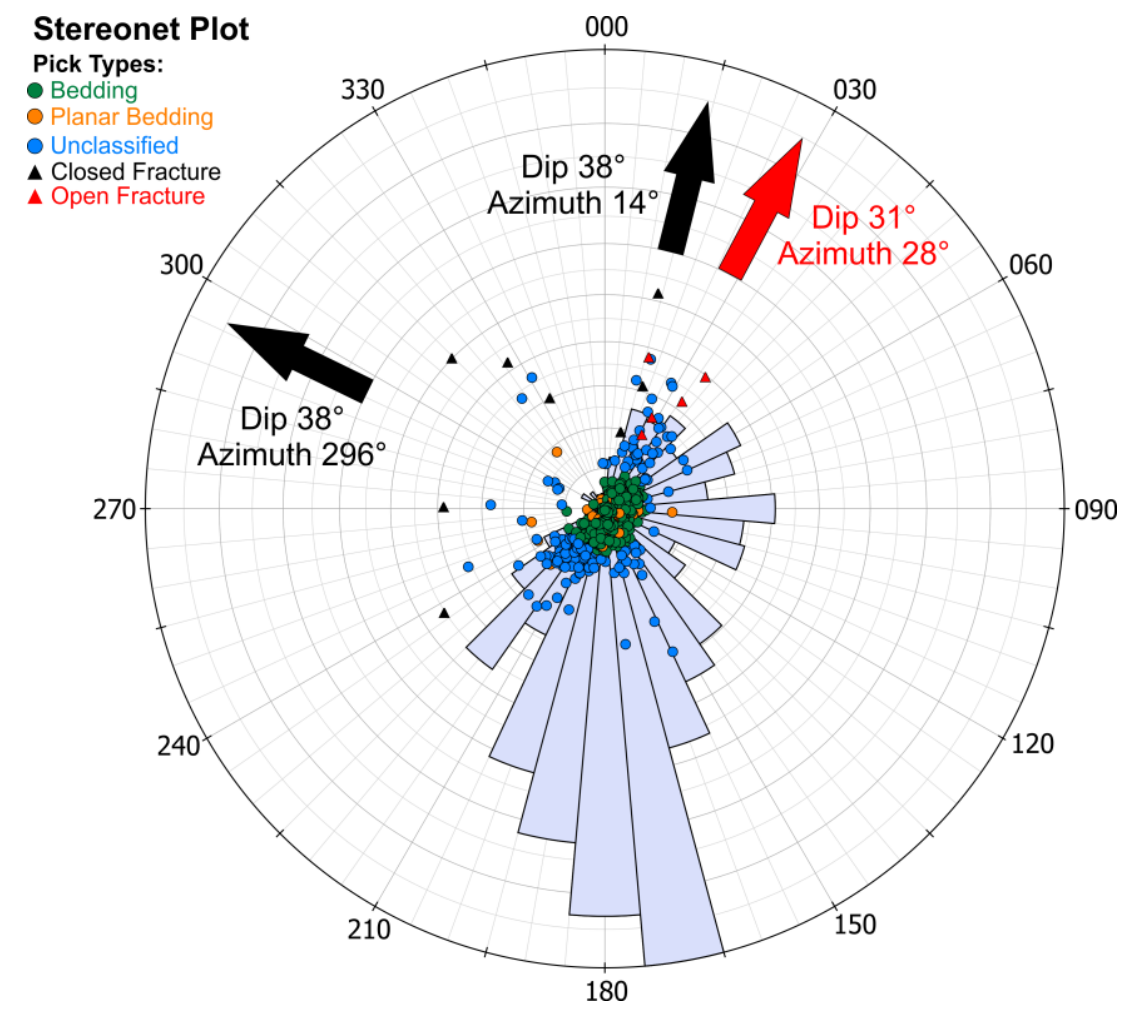

Fig. 3. Stereonet plot showing the dip angles and dip azimuths of the features picked on the borehole electrical image. The dip azimuths frequency is computed using $10^{\circ}$ bins. The circles represent dip angle increments of $10^{\circ}$. The arrows indicate the average dip azimuth of open and closed fractures identified on the imaged interval.

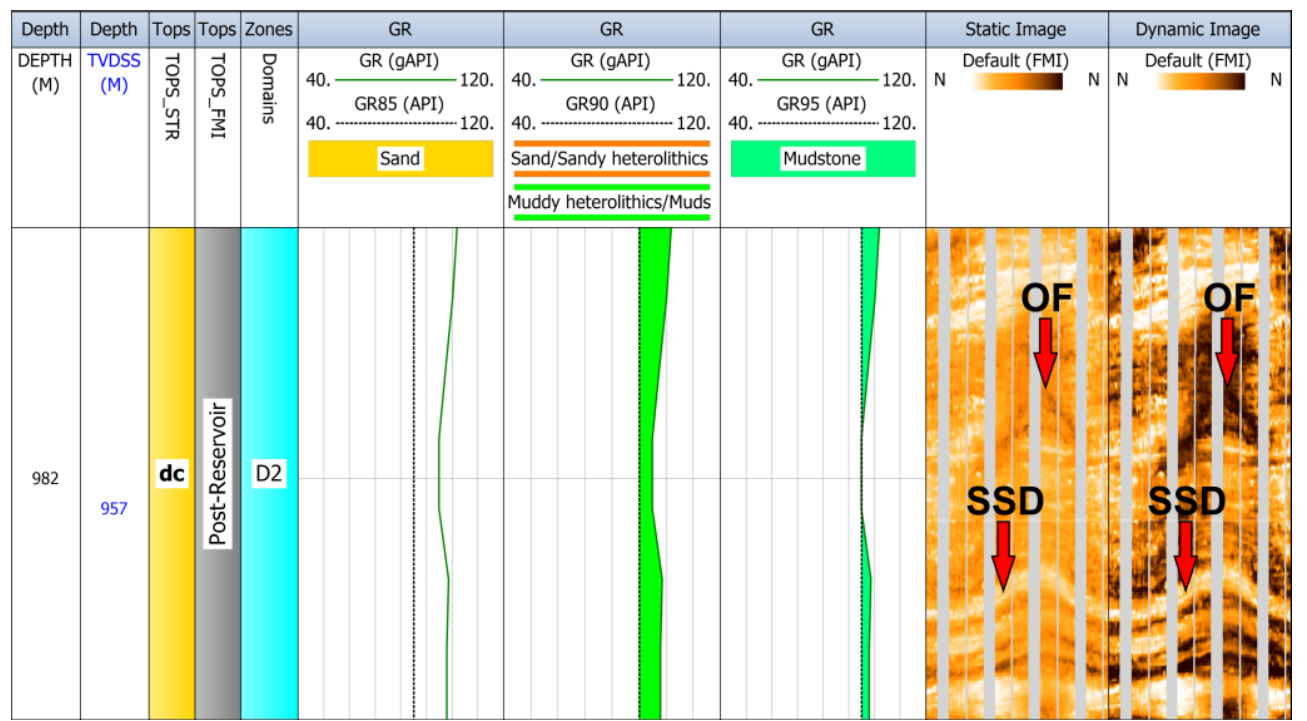

Fig. 4. Static and dynamic borehole electrical images, 981.5-982.5 m interval: example of open/conductive fractures (OF) and soft sediment deformation (SSD). 


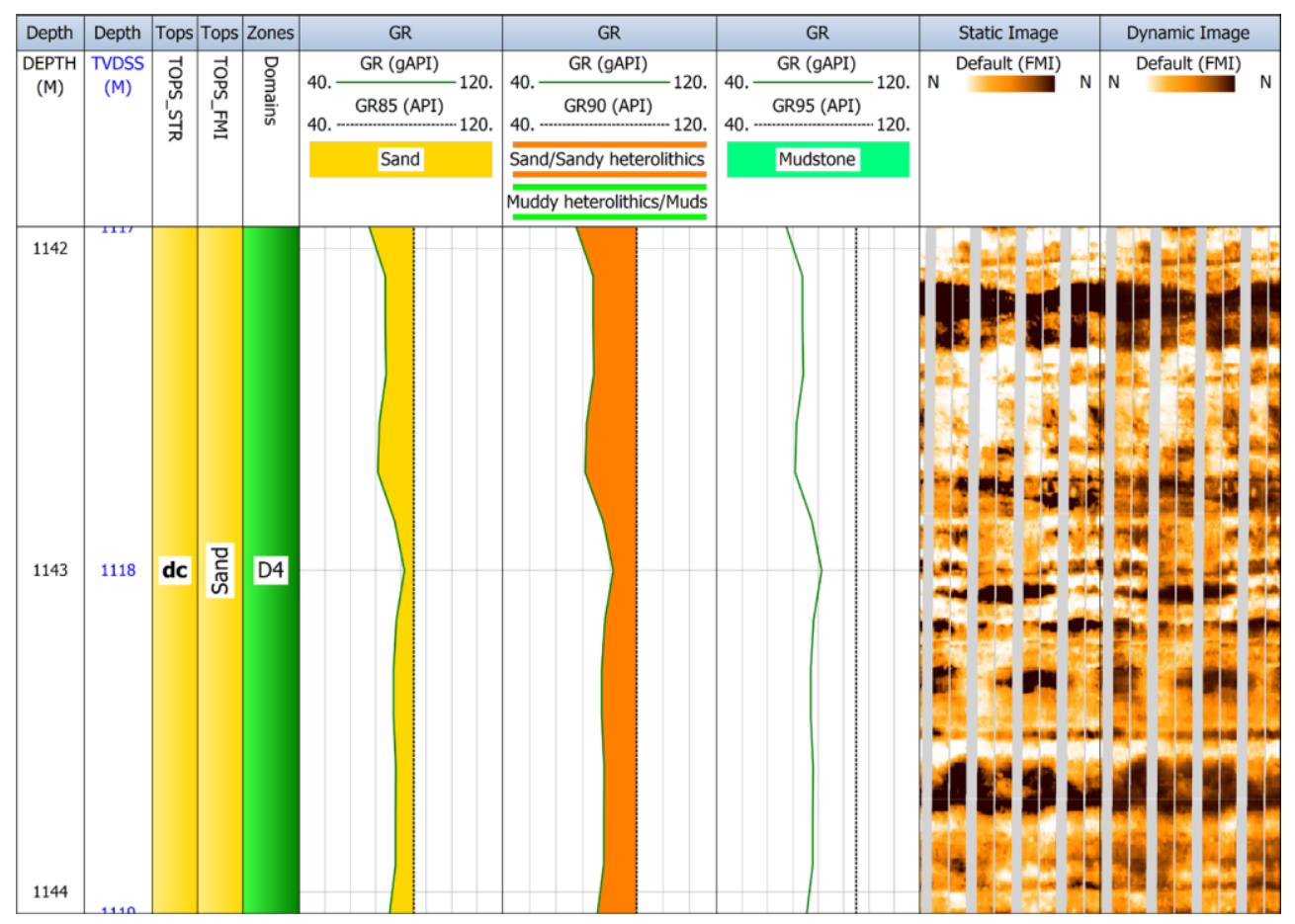

Figure 5. Static and dynamic borehole electrical images, 1142-1144 m interval ("Sand" gas-bearing reservoir): example of strongly bioturbated character of the sediments, indicated by a mottled fabric. Clean sands appear as resistive (light) beds, argillaceous sands appear as conductive (dark) beds

From a sedimentological viewpoint, the electrical images from the analyzed exploration well show a dominance of planar bedding and slumping. Slump structures are abundant mostly within the mudstones/shales forming the domain D2 (Fig. 4). In sands/sandstones there is no direct evidence of cross-bedding, although some steeper sedimentary dips (up to $19^{\circ}$ ) occur. In all lithology types, bioturbation was found to be common and locally intense.

Bioturbation intensity is a measure of the level of destruction of sedimentary fabric as an effect of burrowing fauna existing within sediments. Where the sediments contain no fauna, or there is sparse bioturbation, the depositional features will be preserved. This may be the result of stressed environmental conditions related to low salinity and fresh to brackish water environment, exposure, high sedimentation rate, and oxygen deficiency. In contrast, where the intensity of bioturbation is high, this is an indication of an abundant fauna and suggests greater marine influence, a highly stable environment, low environmental stress, low sedimentation rates, well-oxygenated conditions, favorable salinity and ambient temperatures.

At least six stacked upward-sanding successions can be identified in the domain D1, being interpreted as offshore to lower shoreface parasequences. Only one parasequence (778.3$792.2 \mathrm{~m}$ ) shows a low intensity of bioturbation and is interpreted as reflecting low salinity, fresh to brackish water environment. The remaining parasequences are strongly bioturbated, indicating a well-established marine influence.

The domain D4 shows an overall upward-sanding character, with the "Sand" and "Silt" reservoirs forming the uppermost part of the succession. The domain includes several upward-sanding sub-intervals interpreted as offshore to shoreface parasequences. They show progressively greater shoreface influence upwards, with the "Sand" reservoir comprising mostly lower shoreface facies. 
The overall intensity of bioturbation varies between parasequences, the lower ones exhibiting a low intensity whereas the upper two parasequences are abundantly bioturbated (Fig. 5). As in the case of domain D1, the changes in the bioturbation intensity from domain D4 are considered to reflect the influence of salinity upon colonization of the sediments by organisms. This observation is compatible with models for the Black Sea showing salinity fluctuations associated with intermittent connectivity with the Mediterranean Sea.

\section{Conclusions}

We analyzed borehole electrical imaging data recorded in the 8.5-inch section of a gas exploration well from the Romanian offshore area of western Black Sea. The 649-1272 m imaged interval included Pliocene (Romanian and Dacian stages) to Late Miocene (Pontian stage) deposits, including a biogenic gas reservoir hosted in Dacian (Early Pliocene) shallow marine sands and silts.

Overall, a shallow structural dip towards S-SSE characterizes the study interval. Four structural dip domains were interpreted from the 824 features picked on the electrical image. Domains D1 and D3 are quasi-horizontal, Domain D2 (Middle Dacian) shows dips towards SW and E-NE and is dominantly deformed, small-scale slump features and possible sediment creep being observed, whereas domain D4 (Late Pontian-Early Dacian) shows slightly inclined bedding dips towards S-SSE. Resistive/closed and conductive/open fractures, with moderately shallow dips $\left(31^{\circ}-38^{\circ}\right)$, were identified in domains D1 and especially D2. The opposing directions of the resistive and conductive fractures (ENE-WSW to N-S and ESEWNW, respectively) suggest a possible relationship to the regional tectonic stress. Sedimentological interpretation of domains D1 and D4 shows that progradational offshore to lower shoreface parasequences prevail in both intervals. The observed intensity of bioturbation varies between parasequences, most likely reflecting the Pliocene-Late Miocene water salinity changes in the Black Sea basin.

\section{References}

1. M. Rider, The Geological Interpretation of Well Logs (Second Edition), Rider-French Consulting Ltd., Sutherland, Scotland, ISBN 0-9541906-0-2 (2002)

2. G. Asquith, D. Krygowski, Basic Well Log Analysis (Second Edition), The American Association of Petroleum Geologists (AAPG), Tulsa, Oklahoma, ISBN 0-89181-667-4 (2004)

3. I. Moroşanu, Romanian Continental Plateau of the Black Sea: Tectonic-Sedimentary Evolution and Hydrocarbon Potential, Oscar Print Publishing House, Bucharest, Romania, ISBN 978-973-668-167-7 (2007)

4. I. Moroşanu, The hydrocarbon potential of the Romanian Black Sea continental plateau, Romanian Journal of Earth Sciences 86, 2, 91-109 (2012)

5. C. Konerding, C. Dinu, H.K. Wong, Seismic sequence stratigraphy, structure and subsidence history of the Romanian Black Sea shelf. In: M. Sosson, N. Kaymakci, R.A. Stephenson, F. Bergerat, V. Starostenko (eds.) Sedimentary Basin Tectonics from the Black Sea and Caucasus to the Arabian Platform, Geological Society, London, Special Publications 340, 159-180 (2010)

6. B.M. Niculescu, G. Andrei, Formation Evaluation Challenges in Pliocene Gas-bearing Reservoirs from the Romanian Western Black Sea Shelf, "APPLIED GEOPHYSICS $2018^{\prime \prime}-4^{\text {th }}$ International Conference on Applied Geophysics, Proceedings - E3S Web Conf. 66, 01004 (2018) https://doi.org/10.1051/e3sconf/20186601004 